NEUROMUSCULAR AND BIOMECHANICAL FACTORS

\section{What We Know}

1. The ACL is loaded by a variety of combined sagittal and nonsagittal mechanisms during dynamic sport postures considered to be high risk. ${ }^{1-6}$

2. In vivo strain of the ACL is related to maximal load and timing of ground reaction forces. 7,8

3. Females typically display a more erect (upright) posture when contacting the ground during the early stages of deceleration tasks. ${ }^{9-12}$

4. Maturation influences biomechanical and neuromuscular factors. ${ }^{13-20}$

5. Fatigue alters lower limb biomechanical and neuromuscular factors suggested to increase ACL injury risk.2,21-23 The effect of fatigue is most pronounced when combined with unanticipated landings, causing substantial central processing and central control compromise. 24
6. Trunk and upper body mechanics influence lower extremity biomechanical and neuromuscular factors. $12,25,26$

7. Hip position and stiffness influence lower extremity biomechanical factors. ${ }^{2,10,27}$

\section{What We Don't Know}

1. We still do not know the biomechanical and neuromuscular profiles that cause noncontact ACL rupture. An understanding of the causes is central to identifying how to prescreen at-risk individuals.

2. We do not yet understand the role of neuromuscular and biomechanical variability in the risk of indirect or noncontact ACL injury. Are there optimal levels of variability, and do deviations from these optimal levels increase the risk of injury?

3. Is noncontact ACL injury an unpreventable accident stemming from some form of cognitive dissociation 
that drives central factors and the resulting neuromuscular and biomechanical patterns?

4. Is gross failure of the ACL caused by a single episode or multiple episodes?

5. Is noncontact ACL injury governed by single or potentially multiple high-risk biomechanical and neuromuscular profiles?

\section{Where We Go From Here}

1. To best understand movement patterns linked to noncontact ACL injury, authors should include comprehensive kinetic, kinematic, and neuromuscular (strength, postural stability, activation, and timing) profiles (henceforth referred to as neuromechanics).

2. We need to improve our understanding of neuromechanical variability within and between individuals as it relates to injury risk and injury mechanisms.

3. To fully appreciate joint loading profiles, we must better understand the interaction of anatomical structure, laxity, and neuromechanics.

4. Neuromechanical assessments of different tasks that mimic the mechanical demands commonly associated with sport-specific injury mechanisms should be performed with the testing methods and interpretations particular to the task demands.

5. Neuromechanical factors predicting ACL injuries need to be identified from prospective data.

6. We must develop tasks designed to stress the joint systems that mimic injury mechanisms and are realistic to the mechanistic purpose of the study. Further, musculoskeletal models describing cause-and-effect relationships need to be studied explicitly within a realistic injury scenario.

7. We should determine if a critical threshold of structural or functional weakness exists at which compensatory strategies become evident.

8. We need to continue to expand research models and analyses to include assessments of central processes (automaticity, reaction time, etc), cognitive processes (decision making, focus and attention, prior experience [expert versus novice, etc]), and metacognitive processes (monitoring psychomotor processes, etc).

9. Further understanding of the influence of the head, arms, and trunk segment on lower extremity neuromechanics is important.

10. Further understanding of the influence of the maturational process on lower extremity neuromechanics is necessary.

11. Work that translates laboratory measures to the field and field measures to the laboratory needs to be performed to help with the interpretation of field and laboratory findings. Validating commonly performed field assessment (eg, squatting, landing, etc) to known neuromechanics profiles is essential.

12. Technology must continue to advance and evolve to help us better understand in vivo mechanics, allow more precise transverse-plane measurements, and improve the accuracy and ease of use of measurement techniques in general.

\section{REFERENCES}

1. Markolf KL, Burchfield DM, Shapiro MM, Shepard MF, Finerman GA, Slauterbeck JL. Combined knee loading states that generate high anterior cruciate ligament forces. J Orthop Res. 1995;13(6):930-935.

2. McLean SG, Huang X, Su A, Van Den Bogert AJ. Sagittal plane biomechanics cannot injure the ACL during sidestep cutting. Clin Biomech (Bristol, Avon). 2004;19(8):828-838.

3. Shimokochi Y, Shultz SJ. Mechanisms of noncontact anterior cruciate ligament injury. J Athl Train. 2008;43(3):396-408.

4. Withrow TJ, Huston LJ, Wojtys EM, Ashton-Miller JA. The effect of an impulsive knee valgus moment on in vitro relative ACL strain during a simulated jump landing. Clin Biomech (Bristol, Avon). 2006;21(9):977-983.

5. $\mathrm{Yu}$ B, Garrett WE. Mechanisms of non-contact ACL injuries. Br J Sports Med. Aug 2007;41(suppl 1):i47-i51.

6. Shin CS, Chaudhari AM, Andriacchi TP. The influence of deceleration forces on ACL strain during single-leg landing: a simulation study. J Biomech. 2007;40(5):1145-1152.

7. Cerulli G, Benoit DL, Lamontagne M, Caraffa A, Liti A. In vivo anterior cruciate ligament strain behaviour during a rapid deceleration movement: case report. Knee Surg Sports Traumatol Arthrosc. 2003;11(5):307-311.

8. Withrow TJ, Huston LJ, Wojtys EM, Ashton-Miller JA. The relationship between quadriceps muscle force, knee flexion, and anterior cruciate ligament strain in an in vitro simulated jump landing. Am J Sports Med. 2006;34(2):269-274.

9. Schmitz RJ, Kulas AS, Perrin DH, Riemann BL, Shultz SJ. Sex differences in lower extremity biomechanics during single leg landings. Clin Biomech (Bristol, Avon). 2007;22(6):681-688.

10. Pollard CD, Sigward SM, Powers CM. Gender differences in hip joint kinematics and kinetics during side-step cutting maneuver. Clin J Sport Med. 2007;17(1):38-42.

11. Decker MJ, Torry MR, Wyland DJ, Sterett WI, Steadman RJ. Gender differences in lower extremity kinematics, kinetics and energy absorption during landing. Clin Biomech (Bristol, Avon). 2003;18(7):662-669.

12. Houck JR, Duncan A, De Haven KE. Comparison of frontal plane trunk kinematics and hip and knee moments during anticipated and unanticipated walking and side step cutting tasks. Gait Posture. 2006;24(3):314-322.

13. Barber-Westin SD, Galloway M, Noyes FR, Corbett G, Walsh C. Assessment of lower limb neuromuscular control in prepubescent athletes. Am J Sports Med. 2005;33(12):1853-1860.

14. Barber-Westin SD, Noyes FR, Galloway M. Jump-land characteristics and muscle strength development in young athletes: a gender comparison of 1140 athletes 9 to 17 years of age. Am J Sports Med. 2006;34(3):375-384.

15. Hewett TE, Myer GD, Ford KR. Decrease in neuromuscular control about the knee with maturation in female athletes. $J$ Bone Joint Surg Am. 2004;86(8):1601-1608.

16. Noyes FR, Barber-Westin SD, Fleckenstein C, Walsh C, West J. The drop-jump screening test: difference in lower limb control by gender and effect of neuromuscular training in female athletes. Am J Sports Med. 2005;33(2):197-207.

17. Quatman CE, Ford KR, Myer GD, Hewett TE. Maturation leads to gender differences in landing force and vertical jump performance: a longitudinal study. Am J Sports Med. 2006;34(5):806-813.

18. Hass CJ, Schick EA, Tillman MD, Chow JW, Brunt D, Cauraugh JH. Knee biomechanics during landings: comparison of pre- and postpubescent females. Med Sci Sports Exerc. 2005;37(1):100-107.

19. Russell PJ, Croce RV, Swartz EE, Decoster LC. Knee-muscle activation during landings: developmental and gender comparisons. Med Sci Sports Exerc. 2007;39(1):159-170.

20. Swartz EE, Decoster LC, Russell PJ, Croce RV. Effects of developmental stage and sex on lower extremity kinematics and vertical ground reaction forces during landing. J Athl Train. 2005;40(1):9-14. 
21. Chappell JD, Herman DC, Knight BS, Kirkendall DT, Garrett WE, $\mathrm{Yu}$ B. Effect of fatigue on knee kinetics and kinematics in stop-jump tasks. Am J Sports Med. 2005;33(7):1022-1029.

22. Kernozek TW, Torry MR, Iwasaki M. Gender differences in lower extremity landing mechanics caused by neuromuscular fatigue. Am J Sports Med. 2008;36(3):554-565.

23. Orishimo KF, Kremenic IJ. Effect of fatigue on single-leg hop landing biomechanics. J Appl Biomech. 2006;22(4):245-254.

24. Blackburn JT, Padua DA. Influence of trunk flexion on hip and knee joint kinematics during a controlled drop landing. Clin Biomech (Bristol, Avon). 2008;23(3):313-319.
25. Kulas A, Zalewski P, Hortobagyi T, DeVita P. Effects of added trunk load and corresponding trunk position adaptations on lower extremity biomechanics during drop-landings. J Biomech. 2008;41(1): 180-185.

26. Chaudhari AM, Hearn BK, Andriacchi TP. Sport-dependent variations in arm position during single-limb landing influence knee loading: implications for anterior cruciate ligament injury. Am J Sports Med. 2005;33(6):824-830.

27. Chaudhari AM, Andriacchi TP. The mechanical consequences of dynamic frontal plane limb alignment for non-contact ACL injury. J Biomech. 2006;39(2):330-338. 